\title{
UPAYA PENCEGAHAN BAHAYA DAN ADVERSE EVENTS DI LINGKUANGAN RUMAH SAKIT
}

\author{
Kristina N Tampubolon \\ kristinatampubolon381@gmail.com
}

\begin{abstract}
ABSTRAK
Keselamatan menjadi isu global dan terangkum dalam lima isu penting yang terkait di rumah sakit yaitu keselamatan pasien, keselamatan pekerja atau petugas kesehatan, keselamatan bangunan dan peralatan di rumah sakit, keselamatan lingkungan dan keselamatan bisnis rumah sakit yang terkait dengan kelangsungan hidup rumah sakit. Mengingat masalah keselamatan pasien merupakan masalah yang perlu ditangani segera maka diperlukan standar keselamatan pasien fasilitas pelayanan kesehatan yang merupakan acuan untuk melaksanakan kegiatannya. Persepsi pasien dan keluarga tentang penyebab penyakit dan cara mengatasinya masih bervariasi. Orang tua, pasangan, dan anak merupakan anggota keluarga yang paling menguatirkan kondisi pasien. Beberapa klien/pasien merasa ada stresor dalam keluarganya. Sumber stresor bervariasi antara lain sosial ekonomi, keluarga, pekerjaan, dan diri sendiri. Dukungan kepada pasien berupa dukungan emosional dan finansial yang diberikan oleh anggota keluarga sesuai kemampuan masing-masing. Disimpulkan keluarga berperan sebagai faktor pendukung dan penghambat dalam pengelolaan kasus di layanan primer untuk menunjang pengelolaan lebih berorientasi kepada pasien dan keluarga.Maka dari itu,peranan pasien dan keluarga sebagai partner di pelayanan kesehatan sangat penting untuk mencegah bahaya dan adverse events di Rumah Sakit.

Kata Kunci : Peran pasien dan Keluarga, Keselamatan Pasien, Lingkungan Rumah Sakit, Bahaya dan Adverse Events, Pelayanan Kesehatan.
\end{abstract}




\section{A. LATAR BELAKANG}

Keselamatan menjadi isu global dan terangkum dalam lima isu penting yang terkait di rumah sakit yaitu keselamatan pasien, keselamatan pekerja atau petugas kesehatan, keselamatan bangunan dan peralatan di rumah sakit yang bisa berdampak terhadap keselamatan pasien dan petugas. Keselamatan lingkungan yang berdampak terhadap pencemaran lingkungan dan keselamatan bisnis rumah sakit yang terkait dengan kelangsungan hidup rumah sakit.

Keselamatan pasien merupakan prioritas utama untuk dilaksanakan terkait dengan isu mutu dan citra perumahsakitan. Gerakan (Patient Safety) keselamatan pasien telah menjadi spirit dalam pelayanan rumah sakit seluruh dunia tidak hanya rumah sakit di negara maju yang menerapkan keselamatan pasien untuk menjamin mutu pelayanan, tetapi juga rumah sakit di negara berkembang seperti di Indonesia.

Kementerian Kesehatan Republik Indonesia telah mengeluarkan Peraturan Menteri Kesehatan No. 11 Tahun 2017 tentang Keselamatan Pasien di Rumah Sakit. Peraturan ini menjadi tonggak utama operasionalisasi keselamatan pasien di rumah sakit seluruh Indonesia. Banyak rumah sakit di Indonesia yang telah berupaya membangun dan mengembangkan keselamatan pasien, namun upaya tersebut dilaksanakan berdasarkan pemahaman manajemen terhadap keselamatan pasien. Peraturan menteri ini memberikan panduan bagi manajemen rumah sakit agar dapat menjalankan spirit keselamatan pasien secara utuh.

Keselamatan Pasien adalah suatu sistem yang membuat asuhan pasien lebih aman, meliputi assesment risiko, identifikasi dan pengelolaan risiko pasien, pelaporan dan analisis insiden, kemampuan belajar dari insiden dan tindak lanjutnya, serta implementasi solusi untuk meminimalkan timbulnya risiko dan mencegah terjadinya cedera yang disebabkan oleh kesalahan akibat melaksanakan suatu tindakan atau tidak mengambil tindakan yang seharusnya diambil.Insiden keselamatan pasien(adverse events) dianggap sebagagai bahaya yang meliputi Kejadian Tidak Cedera (KTC), Kejadian Tidak Diharapkan (KTD) dan Kejadian Potensi Cedera (KPC).

Oleh karena itu,dalam karya tulis ilmiah ini akan membahas upaya pencegahan insiden atau kejadian-kejadian yang tidak diharapkan yang terjadi di RumahSakit. 


\section{B. METODE}

Dalam karya ilmiah ini penulis menggunakan metode kepustakaan dengan cara membaca berbagai sumber seperti : buku,ebook,jurnal,karya ilmiah,dan sumber lainnya yang dapat dipercaya dikarenakan agar setiap pembaca tidak dipusingkan dengan artikelartikel yang kurang efektif dan belum dianalisis kebenarannya.Sumber-sumber yang dibaca dan dicari penulis juga berkenaan dengan materi permasalahan yang akan dibahas oleh penulis sehingga sistematis yang dibahas selalu berhubungan dan dapat mempermudah pemahaman pembaca.

\section{HASIL}

Keselamatan Pasien (Patient Safety) merupakan sesuatu yang jauh lebih penting dari pada sekedar efisiensi pelayanan. Perilaku perawat dengan kemampuan perawat sangat berperan penting dalam pelaksanaan keselamatan pasien. Perilaku yang tidak aman, lupa, kurangnya perhatian/motivasi, kecerobohan, tidak teliti dan kemampuan yang tidak memperdulikan dan menjaga keselamatan pasien berisiko untuk terjadinya kesalahan dan akan mengakibatkan cedera pada pasien, berupa Near Miss (Kejadian Nyaris Cedera/KNC) atau Adverse Event(Kejadian Tidak Diharapkan/KTD) selanjutnya pengurangan kesalahan dapat dicapai dengan memodifikasi perilaku.

Perawat harus melibatkan kognitif, afektif dan tindakan yang mengutamakan keselamatan pasien.Keselamatan pasien merupakan masalah keseahatan masyarakat global yang serius.

Keselamatan pasien (patient safety) rumah sakit merupakan suatu sistem dimana rumah sakit membuat asuhan pasien lebih aman. Sistem tersebut terdiri dari: assesmen resiko, identifikasi dan pengelolaan hal yang berhubungan dengan resiko pasien, pelaporan dan analisis insiden, kemampuan belajar dari insiden dan tindak lanjutnya serta implementasi solusi untuk meminimalkan timbulnya resiko. Sistem tersebut diharapkan dapat mencegah terjadinya cedera yang disebabkanoleh kesalahan akibat melaksanakan suatu tindakan atau tidak melakukan tindakan yang seharusnya dilakukan.

Pengelolaan keselamatan pasien dalam pelayanan di rumah sakit berguna untuk mengurangi tingkat kecacatan atau kesalahan dalam memberikan pelayanan kepada pasien. 
Kecelakaan lebih mungkin terjadi dalam beberapa jenis sistem. Ketika kesalahan terjadi, merupakan kegagalan dalam cara merancang sistem. Tujuan utama dari desain sistem agar kecelakaan tidak terjadi dan jikapun kesalahan terjadi dapat meminimalkan kerusakan.Dalam system yang kompleks, salah satu komponen system dapat berinteraksi dengan beberapa komponen lain, kadang-kadang dalam cara yang tak terduga atau tak terlihat.Meskipun semua sistem memiliki banyak bagian yang berinteraksi, masalah muncul ketika salah satu bagian sistem melayani banyak fungsi,dan jika bagian sistem ini gagal, maka semua fungsi akan gagal juga. Sistem yang kompleks ditandai oleh spesialisasi dan keterkaitan menerima informasi secara tidak langsung,dan karena spesialisasi ada sedikit kemungkinan mengganti atau pemindahan personil atau sumber daya lainnya. Oleh karena itu, system dalam pelayanan keselamatan pasien merupakan prioritas utama untuk dilaksanakan di rumah sakit agar dapat mencegah bahaya dari adverse events atau kejadian yang tidak diinginkan.

\section{PEMBAHASAN}

Keselamatan pasien adalah menghindari atau mengurangi hingga ketingkat yang dapat diterima dari bahaya aktual atau risiko dari pelayanan kesehatan atau lingkungan dimana pelayanan kesehatan diberikan.Fokus dari definisi ini adalah untuk mencegah hasil pelayanan kesehatan yang merugikan pasien atau yang tidak diinginkan.

Patient Safety atau keselamatan pasien merupakan isu global yang mempengaruhi negara-negara di semua tingkat pembangunan. Meskipun perkiraan ukuran permasalahan masih belum pasti,khususnya di negara berkembang dan Negara transisi/konflik, ada kemungkinan bahwa jutaan pasien seluruh dunia menderita cacat,cedera atau meninggal setiap tahun karena pelayanan kesehatan yang tidak aman.Mengurangi kejadian yang membahayakan bagi pasien merupakan masalah dalam pelayanan kesehatan bagi setiap orang, dan terdapat banyak hal yang harus dipelajari dan dibagi antara negara-negara maju dengan negara-negara berkembang dan negara dalam transisi/konflik tentang masalah keselamatan pasien.

WHO juga mengingatkan bahwa "keselamatan pasien tidak hanya tentang data statistik tetapi melibatkan kerusakan yang nyata pada kehidupan orang-orang". Oleh karenanya semua strategi dan program keselamatan pasien harus menjadi prioritas dalam 
pelayanan kesehatan. Pasien, professional kesehatan dan pembuat kebijakan semua harus bekerja sama untuk membangun sistem kesehatan yang lebih aman.

Untuk berfungsinya peran secara adequat merupakan hal yang sangat penting bukan hanya untuk berfungsinya individu secara sukses melainkan juga untuk keberhasilan fungsi keluarga. Keluarga memiliki fungsi yang salah satunya adalah tugas kesehatan keluarga yaitu keluarga mampu memberi perawatan pada anggota keluarga yang sakit, keluarga mampu mempertahankan/ menciptkan suasana rumah yang sehat dan keluarga mampu membuat keputusan tindakan kesehatan yang tepat.

\section{Insiden keselamatan pasien akibat salah Pelayanan Kesehatan dan Kegagalan}

\section{Sistem Medis :}

Sebagian besar informasi yang ada tentang risiko keselamatan pasien di rangkaian perawatan kesehatan primer berasal dari penelitian tentang kesalahan dan kejadian yang dilaporkan, termasuk penelitian yang telah mencoba mengembangkan taksonomi untuk mengklasifikasikan jenis kesalahan dan insiden yang terjadi.Adapun istilah insiden keselamatan pasien yang telah dikenal secara luas berikut definisinya yaitu:

1. Insiden Keselamatan Pasien (IKP) / Patient Safety Incident adalah setiap kejadian atau situasi yang dapat mengakibatkan atau berpotensi mengakibatkan harm (penyakit, cedera, cacat, kematian dan lain-lain) yang tidak seharusnya terjadi.

2. Kejadian Tidak Diharapkan (KTD) / Adverse Event adalah suatu kejadian yang mengakibatkan cedera yang tidak diharapkan pada pasien karena suatu tindakan (“commission") atau karena tidak bertindak (“omission”), bukan karena "underlying disease" atau kondisi pasien.

3. Kejadian Nyaris Cedera (KNC) / Near Miss adalah suatu insiden yang belum sampai terpapar ke pasien sehingga tidak menyebabkan cedera pada pasien.

4. Kejadian Tidak Cedera (KTC) adalah insiden yang sudah terpapar ke pasien, tetapi tidak menimbulkan cedera, dapat terjadi karena "keberuntungan" (misal: pasien terima suatu obat kontra indikasi tetapi tidak timbul reaksi obat), atau "peringanan" (suatu obat dengan reaksi alergi diberikan, diketahui secara dini lalu diberikan antidotumnya). 
5. Kondisi Potensial Cedera (KPC) / "reportable circumstance" adalah kondisi yang sangat berpotensi untuk menimbukan cedera, tetapi belum terjadi insiden.

6. Kejadian Sentinel (Sentinel Event) yaitu suatu KTD yang mengakibatkan kematian atau cedera yang diharapkan atau tidak dapat diterima seperti: operasi pada bagian tubuh yang salah. Pemilihan kata "sentinel" terkait dengan keseriusan cedera yang terjadi (misalnya Amputasi pada kaki yang salah, dan sebagainya) sehingga pencarian fakta terhadap kejadian ini mengungkapkan adanya masalah yang serius pada kebijakan dan prosedur yang berlaku.

Keselamatan pasien (patient safety) merupakan suatu variabel untuk mengukur dan mengevaluasi kualitas pelayanan keperawatan yang berdampak terhadap pelayanan kesehatan. Program keselamatan pasien adalah suatu usaha untuk menurunkan angka kejadian tidak diharapkan (KTD). Area keselamatan pasien yang paling memerlukan pengembangan adalah upaya pencegahan KTD.

Kejadian yang tidak diharapkan (KTD atau Adverse Events (AEs) yang disebabkan oleh kesalahan pengobatan/treatment serta dapat berdampak negatif bahkan fatal pada pasien, tenaga medis dan rumah sakit. KTD merupakan suatu kejadian yang tidak diharapkan yang mengakibatkan cedera pada pasien akibat melaksanakan suatu tindakan atau tidak mengambil tindakan yang seharusnya diambil, dan bukan karena penyakit dasarnya atau kondisi pasien. Kejadian tersebut dapat terjadi disemua tahapan dalam perawatan dari diagnosis, pengobatan dan pencegahan.

KTD ada yang dapat di cegah dan ada yang tidak dapat dicegah. KTD yang dapat dicegah berasal dari kesalahan proses asuhan pasien. KTD sebagai dampak dari kesalahan proses asuhan sudah banyak dilaporkan terutama negara maju. KTD yang tidak dapat dicegah adalah suatu kesalahan akibat komplikasi yang tidak dapat dicegah walaupun dengan pengetahuan yang mutakhir.

Memperhatikan kebijakan yang tertuang dalam Permenkes Nomor 1691 Tahun 2011 tentang Keselamatan Pasien bahwa :

Kejadian tidak diharapkan harus dilaporkan dari unit pelayanan Rumah Sakit ke Komite Keselamatan Pasien Rumah Sakit/KKPRS dalam waktu 2 x 24 jam, setelah terjadinya insiden dengan melengkapi formulir laporan insiden. 
Kejadian insiden KTD dengan hasil grading matrixs resiko dan bands biru dan hijau dilakukan investigasi sederhana.

Kejadian insiden KTD dengan hasil grading matrixs resiko dengan bands kuning dan merah dilakukan RCA ( Root Cause Analisis ).

Pada tahun 2007, WHO Collaborating Centre For Patient Safety resmi menerbitkan panduan "Nine Life Solving Patient Safety Solluton" yakni sembilan solusi keselamatan pasien. Untuk meningkatkan keselamatan pasien dan mencegah terjadinya KTD dan KNC, maka perlu diterapkan sembilan solusi keselamatan pasien tersebut di seluruh rumah sakit. Sembilan solusi keselamatan pasien, diantaranya adalah :

a. Perhatikan nama obat, rupa dan ucapan mirip (NORUM/Look-alike, Sound-alike)

b. Pastikan identifikasi pasien

c. Komunikasi yang benar saat serah terima/pengoperan pasien

d. Pastikan tindakan yang benar pada ssi tubuh yang benar

e. Kendalikan cairan elektrolit pekat

f. Pastikan akurasi pemberian obat pada pengalihan pelayanan

g. Hindari salah kateter dan salah sambung selang (tube)

h. Gunakan alat injeksi satu kali pakai

i. Tingkatkan kebersihan tangan (hand hyegiene) untuk pencegahan infeksi nosokomial.

\section{E. PENUTUP}

Keselamatan pasien (patient safety) merupakan suatu variabel untuk mengukur dan mengevaluasi kualitas pelayanan keperawatan yang berdampak terhadap pelayanan kesehatan. Program keselamatan pasien adalah suatu usaha untuk menurunkan angka kejadian tidak diharapkan (KTD). Area keselamatan pasien yang paling memerlukan pengembangan adalah upaya pencegahan KTD. Kejadian yang tidak diharapkan (KTD atau Adverse Events (AEs) yang disebabkan oleh kesalahan pengobatan/treatment serta dapat berdampak negatif bahkan fatal pada pasien, tenaga medis dan rumah sakit. Untuk meningkatkan keselamatan pasien dan mencegah terjadinya KTD dan KNC, maka perlu diterapkan sembilan solusi keselamatan pasien tersebut di seluruh rumah sakit. 


\section{F. DAFTAR PUSTAKA}

Abubakar, N. (2017 ). PENGETAHUAN DAN SIKAP KELUARGA PASIEN RAWAT INAP. JURNAL MANAJEMEN KESEHATAN Yayasan RS. Dr. Soetomo, 3(1), 49-61.

Angelita Lombogia, et.al. (2016). HUBUNGAN PERILAKU DENGAN KEMAMPUAN PERAWAT DALAM MELAKSANAKAN KESELAMATAN PASIEN (PATIENT SAFETY) DI RUANG AKUT INSTALASI GAWAT DARURAT RSUP PROF. DR. R. D. KANDOU MANADO . e-journal Keperawatan (e-Kp),4(2), 1-8.

Ari Pebru Nurlaily.(2017). Hubungan Komitmen Organisasi Dengan Pencegahan Kejadian Tidak Diharapkan (Ktd) Dalam Keselamatan Pasien Di Rumah Sakit Umum Daerah Kabupaten Sukoharjo.Repositori SKRIPSI,Universitas Diponegoro.

Juniarti,Nanda Hani.et.al.(2018). PENERAPAN STANDAR KESELAMATAN PASIEN DI RUMAH SAKIT UMUM DAERAH PROVINSI NUSA TENGGARA BARAT. Jurnal Kesehatan Poltekkes Ternate, 11(2),93-108.

Kamil, H. (2016). PATIENT SAFETY. Idea Nursing Journal,1(1), 1-8.

Nasution, Puteri Citra Cinta Asyura.(2018). Keselamatan Pasien (Patient Safety). Repositori Institusi,Universitas Sumatera Utara

Pipit Festy.(2017). Peran Keluarga Dalam Pelaksanaan Rehabilitasi Medik Pada Pasien Stroke. Repositori SKRIPSI,Universitas Muhammadiyah Surabaya..

Retno A.Werdhani, et. al. (2017). Peran Keluarga dalam Pengelolaan Kasus di Layanan Primer. eJournal Kedokteran Indonesia,3(1), 49 - 61.

Simamora, R. H. (2019). Buku ajar pelaksanaan identifikasi pasien. Uwais Inspirasi Indonesia.

Sinta.(2016). Gambaran Pengetahuan, Motivasi Dan Supervisi Oleh Atasan Langsung Dengan Penerapan Budaya Keselamatan Pasien Oleh Tenaga Kesehatan Pelaksana Di Instalasi Rawat Inap Rumah Sakit Umum Bangli Tahun 2016. Repositori SKRIPSI,Universitas Udayana

.Tutiany,et.al.(2017).Manajemen Keselamatan Pasien.Jakarta :Pusdik SDM Kesehatan. 